\title{
Pengaruh Terapi Bermain Continueing Story Terhadap Kecerdasan Jamak pada Anak Prasekolah
}

\author{
Hindyah Ike Suhariati ${ }^{1, a^{*}}$, Endang Yuswatiningsih ${ }^{2, b}$ \\ ${ }^{1}$ Program Studi S1 Ilmu Keperawatan STIKes Insan Cendekia Medika Jombang, Indonesia \\ ${ }^{2}$ Program Studi S1 Ilmu Keperawatan STIKes Insan Cendekia Medika Jombang, Indonesia \\ a hindyahike@yahoo.com *; b endangramazza@gmail.com \\ * corresponding author
}

\section{ARTICLE INFO}

Keywords

Preschool

Children

Play therapy

Continuing story

Plural intelligence

\section{ABSTRACT}

Intelligence is the highest ability possessed by humans. The purpose of this research is to analyze the effect of play continuing story therapy on plural intelligence in preschool children at TK DWP 2 Lawang General Hospital. The design in this study was Quasi Experiment (Pre and Posttest nonequivalent control group). The affordable population is all preschool age children in Dharma Wanita Persatuan 2 Kindergarten Dr. Radjiman Wediodiningrat Lawang Malang Malang East Java who have problems with multiple intelligence problems as many as 45 children, the sample in this study amounted to 32 children. Analysis of paired data (pre and post-test) on the multiple intelligence variable used the Wilcoxon sign rank test. Mann Whitney Test to test the differences in plural intelligence in the control group and the treatment group after giving treatment. If the statistical test results obtained $\mathrm{p}<0.05$, then $\mathrm{H} 1$ is accepted, it means the research hypothesis is accepted. The results showed play stimulation Continuing Story increased plural intelligence in pre-school age children in TK Dharma Wanita Persatuan 2 RSJ Dr. Radjiman Wediodiningrat Lawang (treatment group) $\mathrm{p}$-value $=0,000$, Play activities according to the curriculum at school increased plural intelligence in preschool-age children Dharma Wanita TK Kindergarten Unity 2 RSJ Dr. Radjiman Wediodiningrat Lawang (control group) pvalue $=0.007$, Plural Intelligence Improvement with play stimulation Continuing Story is higher than the play activities according to the curriculum in the Mann-Whitney Test school $\mathrm{p}$-value $=0,000$. This research concludes that there is an effect of play therapy continuing story on plural intelligence in preschool children in TKP DWP 2 RSJ Lawang.

\section{Pendahuluan}

Kecerdasan merupakan kemampuan tertinggi yang dimiliki oleh manusia. Tingkat kecerdasan dapat membantu seseorang dalam menghadapi berbagai permasalahan yang muncul dalam kehidupannya. Kecerdasan sudah dimiliki sejak manusia lahir dan terus menerus dapat dikembangkan hingga dewasa. Pengembangan kecerdasan akan lebih baik jika dilakukan stimulasi sedini mungkin pada kelima panca indranya. Stimulasi ini bisa dilakukan oleh orangtua saat anak berada di rumah, maupun dilakukan oleh guru di sekolah. Beberapa anak seringkali kita jumpai mengalami hambatan dalam kecerdasannya terutama dalam memunculkan kecerdasan jamak. Banyak faktor yang mempengaruhi, salah satunya adalah kurangnya stimulasi yang dilakukan oleh orang tua, karena orangtua sibuk bekerja, jumlah anak yang terlalu banyak, atau mungkin karena tingkat pemahaman orang tua yang masih kurang dalam melalukan stimulasi pada anaknya. Stimulasi ini sangat bagus apabila dilakukan pada usia prasekolah. Selama lima tahun pertama kehidupan seorang anak otak 
berkembang dengan pesat, terlebih lagi pada usia 2-5 tahun / masa kritis pertama [1].

Data Kemenkes RI pada tahun 2018 didapatkan prosentase sebanyak 88,3\% anak usia 3 sampai 6 tahun di Indonesia mengalami kelainan perkembangan kecerdasan [2]. Berdasarkan studi pendahuluan yang peneliti lakukan pada bulan Januari 2020, 6 dari 10 anak prasekolah di TK DWP 2 RSJ Lawang mengalami hambatan pekembangan kecerdasan jamak.

Kecerdasan merupakan ungkapan dari cara berfikir seseorang yang dapat dijadikan modal dalam belajar. Beberapa faktor penyebab hambatan dalam memunculkan beberapa aspek kecerdasan jamak adalah kurangnya stimulasi, adanya kelainan pada anak misalnya kemampuan berkomunikasi dan mendengar, kesulitan belajar, hal ini dapat berakibat pada kecerdasan jamak yang tidak bisa muncul dengan maksimal. Belajar berkaitan erat dengan kecerdasan, untuk memaksimalkan tingkat kecerdasan diperlukan rangsangan sejak masa pertama kehidupannya. Denninson 2004, dalam Sujiono, 2010 menyatakan belajar adalah kegiatan alami dan menyenangkan, kesulitan belajar adalah ketidakmampuan mengatasi stress, semua orang akan mengalami kesulitan belajar selama.belajar untuk bergerak [1].

Bermain continueing story dapat memunculkan beberapa aspek kecerdasan jamak : 1) pengembangan program kegiatan bermain, 2) kajian tentang otak yang dipentingkan adalah tentang ketrampilan otak yang berhubungan dengan cara berfikir, 3) peranan otak dalam peristiwa belajar. Peristiwa belajar merupakan proses perubahan tingkah laku yang terjadi sepanjang waktu sebagai hasil dari pengalaman. Pada masa usia dini ingatan pertama yang berkembang adalah ingatan mengenali sesuatu yang pernah di indranya, yang dapat dilakukan dengan pemberian terapi bermain continueing story yang dapat memunculkan bebrapa aspek kecerdasan jamak : kecerdasan linguistik, intrapersonal, interpersonal dan visual spastial [1]. Berdasarkan fenomena di atas, maka peneliti tertarik melakukan penelitian dengan judul pengaruh terapi bermain continueing story terhadap kecerdasan jamak pada anak prasekolah di TK DWP 2 RSJ Lawang.

\section{Metode}

Jenis penelitian ini adalah penelitian eksperimen. Penelitian eksperimen merupakan suatu rancangan penelitian yang digunakan untuk mencari hubungan sebab akibat dengan adanya keterlibatan penelitian dalam melakukan manipulasi terhadap variable bebas [3].

Desain penelitian menggunakan Quasi Experiment (Pre and Post test nonequivalent control group ) dimana dalam penelitian ini terdapat dua kelompok sampel yaitu kelompok perlakuan dan kelompok control [3] untuk mengetahui pengaruh terapi bermain continueing story terhadap kecerdasan jamak pada anak prasekolah di TK DWP 2 RSJ Lawang.

Lokasi penelitian dilaksanakan di TK DWP 2 RSJ Lawang tahun 2020. Penelitian ini dilakukan mulai tanggal 10 Februari sampai 7 Maret 2020, setelah mendapatkan surat lulus uji etik dari Komisi Etik Stikes Insan Cendekia Medika Jombang, yang bertujuan untuk melindungi dan menjamin kerahasiaan responden.

Menurut Hikmat (2014) populasi adalah semua objek penelitian dan objek yang akan diteliti. Populasi dalam penelitian ini adalah seluruh anak usia pra sekolah di TK Dharma Wanita Persatuan 2 RSJ Dr Radjiman Wediodiningrat Lawang Kabupaten Malang Jawa Timur yang mengalami masalah hambatan kecerdasan jamak. Jumlah populasi penelitian ini sebanyak 45 anak yang berasal kelas A sebanyak 25 orang, kelas B 20 orang [4].

Sampel dalam penelitian ini diambil dengan menggunakan teknik simple random sampling. Dikatakan simple (sederhana) karena pengambilan anggota sampel dari populasi dilakukan secara acak tanpa memperhatikan strata yang ada dalam populasi itu [5].

Penelitian dimulai dengan mengajukan surat permohonan izin pelaksanaan penelitian pada instansi pendidikan program S1 keperawatan, kemudian surat izin yang diperoleh diajukan kepada kepala sekolah TK Dharma Wanita Persatuan 2 Rumah Sakit Jiwa Dr Radjiman Wediodiningrat Lawang Kabupaten Malang Jawa Timur. Setelah mendapat izin, kemudian peneliti mengumpulkan data.

Analisis univariat dilakukan dengan setiap variabel yang diteliti dimana masing masingmasing variabel akan dibuat gambaran distribusi dan presentasi. Data tersebut ditampilkan dalam bentuk tabel frekuensi.

Analisis bivariat dilakukan untuk : 1) Analisis data berpasangan (pre and post test) pada variabel kecerdasan jamak digunakan uji Wilcoxon sign rank test, 2) Analisis untuk menguji perbedaan kecerdasan jamak pada kelompok kontrol dan kelompok perlakuan digunakan uji Mann 
Whitney dengan tingkat kesalahan $(\alpha)$ 0,05 jika nilai p lebih kecil dari alpha $(\alpha) 0,05$ maka $\mathrm{H} 0$ ditolak artinya ada pengaruh terapi bermain continueing story terhadap kecerdasan jamak pada anak prasekolah di TK DWP 2 RSJ Lawang. Jika nilai p lebih besar dari tingkat kesalahan $(\alpha) 0,05$ maka H0 diterima, artinya tidak ada pengaruh terapi bermain continueing story terhadap kecerdasan jamak pada anak prasekolah di TK DWP 2 RSJ Lawang. Kemudian hasil penelitian dilanjutkan dalam bentuk tabel dan dibahas dengan menggunakan teori dan kepustakaan yang ada.

\section{Hasil dan Diskusi}

\section{Analisa Univariat}

Tabel 1. Distribusi frekuensi Data Demografi Responden di TK Dharma Wanita Persatuan 2 RSJ Dr. Radjiman Wediodiningrat Lawang Maret 2020

\begin{tabular}{llcccc}
\hline \multirow{2}{*}{ No } & Data Demografi & \multicolumn{2}{c}{$\begin{array}{c}\text { Kelompok } \\
\text { Kontrol }\end{array}$} & \multicolumn{2}{c}{$\begin{array}{c}\text { Kelompok } \\
\text { Perlakuan }\end{array}$} \\
\cline { 3 - 6 } & & f & \% & f & \% \\
\hline 1 & Jenis Kelamin & & & & \\
\hline & Laki - laki & 8 & 50 & 5 & 31,2 \\
\hline & Perempuan & 8 & 50 & 11 & 68,8 \\
\hline 2 & Umur & & & & \\
\hline & 4 Tahun & 2 & 12,4 & 2 & 12,4 \\
\hline & 5 Tahun & 7 & 43,8 & 11 & 68,8 \\
\hline & 6 Tahun & 7 & 43,8 & 3 & 18,8 \\
\hline
\end{tabular}

Berdasarkan tabel 1, diketahui bahwa data umum tentang jenis kelamin pada kelompok control laki laki sebanyak 8 orang (50\%) dan perempuan 8 orang (50\%), sedang pada kelompok perlakukan laki laki sebanyak 5 orang $(31,2 \%)$ dan perempuan sebanyak 11 orang $(68,8 \%)$. Data umum tentang umur pada kelompok control yang berumur 4 tahun sebanyak 2 orang $(12,4 \%), 5$ tahun sebanyak 7 orang $(43,8 \%)$ dan 6 tahun sebanyak 7 orang $(43,8 \%)$, sedang pada kelompok perlakuan yang berumur 4 tahun sebanyak 2 orang $(12,4 \%), 5$ tahun sebanyak 11 orang $(68,8 \%)$ dan 6 tahun sebanyak 3 orang $(18,8 \%)$.

Tabel 2. Distribusi frekuendi posisi anak dalam keluarga dan Jumlah Anak di TK Dharma Wanita Persatuan 2 RSJ Dr. Radjiman Wediodiningrat Lawang Maret 2020

\begin{tabular}{|c|c|c|c|c|c|}
\hline \multirow[t]{2}{*}{ No } & \multirow[t]{2}{*}{ Data Demografi } & \multicolumn{2}{|c|}{$\begin{array}{c}\text { Kelompok } \\
\text { Kontrol }\end{array}$} & \multicolumn{2}{|c|}{$\begin{array}{l}\text { Kelompok } \\
\text { Perlakuan }\end{array}$} \\
\hline & & $\mathbf{f}$ & $\%$ & f & $\%$ \\
\hline \multirow[t]{4}{*}{1} & $\begin{array}{l}\text { Posisi Anak } \quad \text { Dalam } \\
\text { Keluarga }\end{array}$ & & & & \\
\hline & Pertama & 11 & 68,8 & 9 & 56,3 \\
\hline & Kedua & 4 & 25 & 6 & 37,5 \\
\hline & Ketiga & 1 & 6,2 & 1 & 6,2 \\
\hline \multirow[t]{4}{*}{2} & Jumlah anak & & & & \\
\hline & Satu & 2 & 12,4 & 1 & 6,2 \\
\hline & dua & 11 & 68,8 & 10 & 62,5 \\
\hline & Tiga & 3 & 18,8 & 5 & 31,3 \\
\hline
\end{tabular}

Berdasarkan tabel 2, posisi anak dalam keluarga untuk kelompok kontrol sebagian besar adalah anak pertama yaitu sebanyak 11 orang $(68,8 \%)$ sedangkan untuk kelompok perlakuan sebagian besar adalah anak pertama yaitu sebanyak 9 orang (56,3\%). Jumlah anak pada kelompok control sebagian besar dengan jumlah anak dua yaitu sebanyak 11 orang $(68,8 \%)$, sedang pada kelompok perlakukan sebagian besar dengan jumlah anak dua yaitu sebanyak 10 orang $(62,5 \%)$. 
Tabel 3. Distribusi Frekuensi Data Demografi Orang Tua Responden di TK Dharma Wanita Persatuan 2 RSJ Dr. Radjiman Wediodiningrat Lawang Maret 2020

\begin{tabular}{|c|c|c|c|c|c|}
\hline \multirow{2}{*}{ No } & \multirow{2}{*}{ Data Demografi } & \multicolumn{2}{|c|}{ Kelompok Kontrol } & \multicolumn{2}{|c|}{ Kelompok Perlakuan } \\
\hline & & f & $\%$ & $\mathbf{f}$ & $\%$ \\
\hline \multirow[t]{5}{*}{1} & Pendidikan Ortu & & & & \\
\hline & SMP & 3 & 18,8 & 3 & 18,8 \\
\hline & SMA & 11 & 68,8 & 11 & 68,8 \\
\hline & D3 & 1 & 6,2 & 2 & 12,4 \\
\hline & S1 & 1 & 6,2 & 0 & 0 \\
\hline \multirow[t]{6}{*}{2} & Pekerjaan Ortu & & & & \\
\hline & Swasta & 10 & 62,5 & 11 & 68,8 \\
\hline & TNI & 3 & 18,8 & 2 & 12,5 \\
\hline & PNS & 1 & 6,2 & 2 & 12,5 \\
\hline & Tani & 1 & 6,3 & 0 & 0 \\
\hline & Buruh & 1 & 6,2 & 1 & 6,2 \\
\hline
\end{tabular}

Berdasarkan tabel 3, data demografi orang tua responden pada kelompok control dan kelompok perlakukan pendidikan orang tua sebagian besar SMA yaitu sebanyak 11 orang $(68,8 \%)$. Pekerjaan orang tua pada kelompok control dan kelompok perlakuan sama yaitu swasta, untuk kelompok control sebanyak 10 orang $(62,5 \%)$ dan pada kelompok perlakukan sebanyak 11 orang $(68,8 \%)$.

Tabel 4. Hasil Penelitian Kecerdasan Jamak Anak Usia Pra Sekolah Pada Kelompok kontrol Dan Kelompok Perlakuan di TK Dharma Wanita Persatuan 2 RSJ Dr. Radjiman Wediodiningrat Lawang

\begin{tabular}{|c|c|c|c|c|c|c|c|c|}
\hline \multirow{3}{*}{ Kategori } & \multicolumn{4}{|c|}{ Kelompok Kontrol } & \multicolumn{4}{|c|}{ Kelompok Perlakuan } \\
\hline & \multicolumn{2}{|c|}{ Pre Test } & \multicolumn{2}{|c|}{ Post Test } & \multicolumn{2}{|c|}{ Pre Test } & \multicolumn{2}{|c|}{ Post Test } \\
\hline & $\sum$ & $\%$ & $\sum$ & $\%$ & $\sum$ & $\%$ & $\sum$ & $\%$ \\
\hline Baik & 0 & 0 & 0 & 0 & 0 & 0 & 7 & 43,7 \\
\hline Cukup & 2 & 12,5 & 4 & 25 & 4 & 25 & 9 & 56,3 \\
\hline Kurang & 14 & 87,5 & 12 & 75 & 12 & 75 & 0 & 0 \\
\hline Jumlah & 16 & 100 & 16 & 100 & 16 & 100 & 16 & 100 \\
\hline
\end{tabular}

Wilcoxon Signed Ranks Test Kontrol p-value $=0,007 \quad$ Perlakuan $p$-value $=0,000$

Mann-Whitney Test $p$-value $=0,000$

Berdasarkan tabel 4, pada kelompok control kecerdasan jamak anak usia pra sekolah sebelum diberikan terapi bermain sebagian besar dengan kategori kurang yaitu sebanyak 14 orang $(87,5 \%)$ dan setelah diberikan terapi bermain sebagian besar dengan kategori kurang yaitu sebanyak 12 orang (75\%). Pada kelompok perlakuan sebelum diberikan terapi bermain sebagian besar dengan kategori kurang yaitu sebanyak 12 orang (75\%) dan setelah diberikan terapi bermain sebagian besar dengan kategori cukup yaitu sebanyak 9 orang $(56,3 \%)$ dan hampir setengahnya dengan kategori baik yaitu sebesar 7 orang $(43,7 \%)$.

\section{Analisa Bivariat}

Analisis Bivariat dalam penelitian ini dilakukan sebanyak dua kali uji, yaitu uji Wilcoxon untuk mengetahui ada tidaknya perbedaan antara sebelum dan sesudah diberikan terapi bermain continuing story dan uji Mann Whitney untuk mengetahui perbedaan 2 kelompok yaitu pada kelompok control dan kelompok perlakuan. Hasil dari uji Wilcoxon didapatkan bahwa untuk kelompok control nilai $\mathrm{p}=0,007<$ alpha 0,05 maka $\mathrm{H} 1$ diterima artinya ada perbedaan antara sebelum dan sesudah diberikan terapi bermain continuing story, sedangkan untuk kelompok perlakuan nilai $\mathrm{p}=0,000<$ alpha 0,05 maka $\mathrm{H} 1$ diterima artinya ada perbedaan antara sebelum dan sesudah diberikan terapi bermain continuing story. Hasil dari uji Mann Whitney didapatkan bahwa nilai $\mathrm{p}=0,000<$ alpha 0,05 maka $\mathrm{H} 1$ diterima artinya ada perbedaan kecerdasan jamak anak usia pra sekolah antara kelompok control dan kelompok perlakuan. 


\section{Pembahasan \\ Pengaruh terapi bermain continueing story terhadap kecerdasan jamak pada anak prasekolah di TK DWP 2 RSJ Lawang}

Berdasarkan tabel 4 hasil uji Wilcoxon menunjukkan ada pengaruh terapi bermain Continueing Story terhadap kecerdasan jamak pada anak prasekolah di TK DWP 2 RSJ Lawang ( $\mathrm{p}=0,000)$. Nilai signifikansi ini menunjukkan bahwa ada pengaruh stimulasi bermain Continueing Story terhadap Kecerdasan Jamak anak usia pra sekolah. Stimulasi bermain Continueing Story meningkatkan Kecerdasan Jamak, hal ini menunjukkan bahwa terapi bermain Continueing Story memberikan stimulus yang baik terhadap perkembangan kecerdasan jamak pada anak prasekolah. Indicator kecerdasan jamak tersebut meliputi : kecerdasan linguistic terlihat saat anak dapat merangkai dua kata untuk mengajukan pertanyaan, menggunakan kata ganti untuk menyebutkan orang lain dan menceritakan suatu kejadian dengan gambar, kecerdasan intrapersonal peneliti bercerita dengan Continueing Story (celemek flanel dan big book) anak dapat menjadi pendengar yang baik dan berkonsentrasi sampai selesai cerita, kecerdasan interpersonal terlihat saat anak berinteraksi dan berani bertanya jawab dengan guru, peneliti dan sesama teman, kecerdasan visual spasial terlihat saat anak bisa menghubungkan isi gambar, memberi arti dan posisi gambar yang dilihat [1].

Teori Piaget menjelaskan cara berpikir, memahami dan belajar. Piaget meyakini bahwa kecerdasan adalah proses kognitif atau mental yang digunakan anak untuk memperoleh pengetahuan. Permainan adalah cara utama anak untuk terlibat secara aktif dengan lingkungannya dan untuk berpikir dan belajar. Permaian Continueing Story dapat memunculkan beberapa aspek kecerdasan jamak [1].

Stimulasi bermain Continueing Story merupakan salah satu bentuk rangsangan dari lingkungan agar anak berfikir, memahami dan belajar dengan teman, guru dan juga perawat.Stimulasi yang dilakukan secara terus menerus akan menumbuhkan aspek kecerdasan jamak pada anak. Pendekatan ini merupakan alat untuk melihat bagaimana pikiran manusia mengoperasikan dunia, baik itu benda yang konkret maupun hal - hal yang abstrak [6].

\section{Pengaruh kegiatan bermain sesuai kurikulum di sekolah terhadap kecerdasan jamak pada anak prasekolah di TK DWP 2 RSJ Lawang}

Hasil penelitian didapatkan kecerdasan jamak pada kelompok kontrol sebagian besar $(87,5 \%)$ pada kategori kurang. Kecerdasan jamak pada kategori kurang ini ditunjukkan responden dengan ketidakmampuan berbahasa anak dalam merangkai kata untuk mengajukan pertanyaan pada guru dan berbicara dengan temannya, tidak bisa menjadi pendengar yang baik dan mengikuti kegiatan bermain dari awal sampai akhir, tidak berani bertanya jawab dengan guru dan temannya serta tidak dapat menghubungkan isi gambar dalam cerita. Guru memberikan pengajaran sesuai dengan kurikulum di sekolah, padahal sebenarnya bisa dimodifikasi dengan permainan, supaya anak lebih mudah dalam mengikuti proses pembelajaran. Hal ini diperkuat oleh teori yang dikemukakan oleh Bandler dan Grinder dalam DePotter (2002), hampir semua orang cenderung pada salah satu modalitas belajar dan berperan sebagai saringan untuk pembelajaran, pemrosesan dan komunikasi [7]. Sebenarnya dalam beberapa hal orangtua ataupun guru mengetahui secara naluriah bahwa anak-anak belajar dengan cara-cara dan gaya yang berbeda [8]. Pemahaman mendalam terhadap kecerdasan individual masing-masing anak dan gaya belajar mereka akan membantu para pendidik dalam menghadapi anak terutama mengajari anak-anak dengan cara yang paling sesuai dengannya atau cara yang paling mudah untuk mereka dapat menguasai suatu pelajaran, menangkap informasi atau berbagai ketrampilan [1].

\section{Perbandingan Kecerdasan Jamak pada Kelompok Perlakuan dan Kelompok Kontrol}

Secara statistik ada pebedaan yang bermakna Kecerdasan Jamak kelompok kontrol sebelum intervensi dan setelah intervensi $(p=0,007)$. Nilai yang signifikan ini menunjukkan bahwa ada pengaruh kegiatan bermain sesuai dengan kurikulum di sekolah terhadap Kecerdasan Jamak anak usia pra sekolah. Akan tetapi kalau dilihat dari kategori Kecerdasan Jamak tidak 
menunjukkan peningkatan yang signifikan, karena hanya 2 anak yang mengalami peningkatan Kecerdasan Jamak dari kategori kurang menjadi cukup. Hal ini dapat dilihat anak tidak berinteraksi dan tidak berani bertanya jawab dengan guru, perawat, dan sesama temannya, tidak dapat merangakai kata untuk mengajukan pertanyaan, tidak bisa menjadi pendengar yang baik dan berkonsentrasi sampai guru/perawat selesai bercerita, serta tidak dapat menghubungkan isi gambar dalam cerita. Bermain adalah dunia anak, demikian ungkapan yang sering kita dengar dari pakar pendidikan anak. Ungkapan tersebut benar adanya, karena anak - anak pada usia prasekolah memahami dunia sekitarnya secara alami melalui bermain. Bagi anak bermain bukan hanya kesenangan, melainkan juga sarana belajar untuk mendapatkan pengetahuan dan pembentukan watak. Untuk mengoptimalkan waktu bermain anak diperlukan adanya program bermain yang terencana, yang dikembangkan berdasarkan tahap - tahap tumbuh kembang dan minat, bakat serta kondisi lingkungan dimana anak tinggal atau rancangan lingkungan dan kurikulum sesuai dengan perkembangan anak/DAP [9]. Menurut para pakar, usia $0-6$ tahun adalah usia emas yang sangat berpengaruh pada kepribadian anak selanjutnya karena perkembangan IQ, EQ dan SQ berkembang sampai $80 \%$ (Sulistiani, 2009).

Berdasarkan hasil uji statistik Mann Whitney ada perbedaan yang sangat bermakna antara kelompok perlakuan dan kelompok kontrol setelah dilakukan intervensi dengan nilai signifikansi $p=0,000$. Nilai signifikansi ini menunjukkan bahwa ada perbedaan Kecerdasan Jamak pada kelompok perlakuan dan kelompok kontrol setelah diberikan intervesi, yaitu peningkatan Kecerdasan Jamak dengan stimulasi bermain Continueing Story lebih tinggi dibandingkan dengan kegiatan bermain sesuai kurikulum di sekolah.

\section{Kesimpulan}

Berdasarkan hasil penelitian dan pembahasan yang telah diuraikan sebelumnya maka diperoleh beberapa kesimpulan yaitu stimulasi bermain Continueing Story meningkatan Kecerdasan Jamak pada anak usia pra sekolah di TK Dharma Wanita Persatuan 2 RSJ Dr Radjiman Wediodiningrat Lawang (kelompok perlakuan), kegiatan bermain sesuai kurikulum di sekolah meningkatkan Kecerdasan Jamak pada anak usia prasekolah TK Dharma Wanita Persatuan 2 RSJ Dr Radjiman Wediodiningrat Lawang (kelompok control) dan peningkatan Kecerdasan Jamak dengan stimulasi bermain Continueing Story lebih tinggi dibandingkan dengan kegiatan bermain sesuai kurikulum di sekolah.

\section{Saran}

Diharapkan bagi guru di TK Dharma Wanita Persatuan 2 RSJ Dr Radjiman Wediodiningrat Lawang dapat menggunakan stimulasi bermain Continueing Story sebagai alternative dalam pembelajaran anak prasekolah.

Diharapkan bagi peneliti selanjutnya dapat melakukan penelitian dengan metode bermain yang lain, seperti Pengaruh stimulasi bermain Creative Dramatic Play terhadap kecerdasan jamak pada anak prasekolah.

\section{Referensi}

[1] Sujiono. (2010). Bermain Kreatif Berbasis Kecerdasan Jamak. Jakarta : PT Indeks.

[2] Kemenkes RI. (2018) Hasil Riset Kesehatan Dasar (Riskesdas) 2018. Jakarta : Badan Penelitian dan Pengembangan Kesehatan Kementerian Kesehatan RI

[3] Nursalam. (2011). Konsep Dan Penerapan Metodologi Penelitian Ilmu Keperawatan. Jakarta: Salemba Medika

[4] Hikmat, M,M., (2014). Metode Penelitian Dalam Perserpektif Ilmu Komunikasi dan Sastra. Yogyakarta: Graha Ilmu.

[5] Sugiyono., (2010). Metode Penelitian Kuantitatif Kualitatif dan R\&D.Bandung: Alfabeta.

[6] Gardner, Howard. (1999). Intelligence Reframed: Multiple Intelligence for 21th Century, USA: Basic Book.

[7] De Porter, Bobbi \& Hernacki, Mike. (2002). Membiasakan Belajar Nyaman dan Menyenangkan. Jakarta: Kaifa 
[8] Dryden, Gorden dan Jeanette Vos. 1999. Revolusi Cara Belajar (bagian 1). Bandung : Kaifa.

[9] Morrison, G. (2012). Dasar - Dasar Pendidikan Anak Usia Dini. Jakarta : PT Indeks.

[10] Sulistiani W., 2009. Penerapan Metode Bermainuntuk Meningkatkan Kemampuan Sosial AnakUsia Dini. Jurnal Ilmiah Psikologi dan Psikologi KelautanKemaritiman. Vol. 3(2). 